\title{
Transformaciones del movimiento villero y las disputas por el bienestar en las políticas urbanas de la Ciudad de Buenos Aires
}

Transformations in the slums movement and the controversies over welfare in Buenos Aires City's urban policies

Julia Nesprias

Becaria de investigación UBACyT, Instituto de Estudios de América Latina y el Caribe, Centro de Estudios de Ciudad, Facultad de Ciencias Sociales, Universidad de Buenos Aires. Maestranda en hábitat y pobreza urbana en América Latina, Facultad de Arquitectura, Diseño y Urbanismo, UBA. jnesprias1@gmail.com

Fecha de recepción:

11.10.20

Fecha de aceptación:

1.2.21

\section{Resumen}

El objetivo de este artículo es ubicar históricamente el movimiento villero en la Ciudad de Buenos Aires y el rol protagónico que asume en las clases populares el componente urbano del bienestar. Para ello se explora el componente reivindicativo de las organizaciones territoriales y los lineamientos de las políticas urbanas dirigidas al sector en los últimos setenta años, desde los orígenes del movimiento, políticamente radicalizado hasta las reformas neoliberales de los años noventa, cuando las demandas asumieron un carácter situado con eje en las problemáticas locales. La hipótesis que subyace en este trabajo es que en ese contexto se fue dando una re-individualización y descolectivización en las prácticas de las organizaciones villeras. También se sostiene que las mismas, poco a poco, abandonaron la impronta de la organización obrera para asumir, en su lugar, nuevas características vinculadas al territorio y a las políticas urbanas orientadas al propio sector. 
Palabras clave: movimiento villero - políticas urbanas - bienestar - politicidad

\begin{abstract}
The goal of these pages is to historically locate the slums organization of the Buenos Aires city and the central role dwellers attach to urban wellbeing. The article focuses on both the demands stemming from these territorial organizations and the policy strategies and actions addressed to them. The historical period selected covers from the movement's politically radicalized the origins questioning the systemic dimensions of the overall social design, to an increasing dedication to local problems. Along this evolution there has also been an increasing re-individualization and decollectivization in the movement's strategies, with growing involvement to urban policies
\end{abstract}

Key-words: slum's movement - city dwellers - urban policies - welfare

\title{
Introducción ${ }^{1}$
}

El objetivo de estas páginas es ubicar históricamente la organización de los habitantes en las villas de la Ciudad de Buenos Aires y el modo en que evolucionaron sus demandas, propuestas y sentidos sobre el bienestar. Se observará la estrecha relación entre el devenir del movimiento villero y las rupturas en las políticas de la historia reciente. A partir de esta relación, pueden interpretarse los cambios en las demandas y reivindicaciones del movimiento y sus reconfiguraciones en el tiempo. Los observables serán el componente reivindicativo de las organizaciones territoriales y los principales lineamientos de las políticas urbanas orientadas al sector.

Se seleccionó para el estudio un período que va desde la radicalización del movimiento en la década de 1970 hasta las reformas neoliberales de los años noventa. Este lapso permite comparar un momento de efervescencia política con niveles robustos de organización, en el cual el movimiento villero estaba políticamente radicalizado, cuestionaba la agenda pública y proponía alternativas al desarrollo nacional, con otro en el cual se advierte el impacto de las reformas neoliberales y las demandas que asumieron un carácter situado con eje en las problemáticas locales. El propósito que guía este recorte es la 
posibilidad de explicar, a partir de retomar el contexto, el desempeño de los actores involucrados y la evolución de la agenda de políticas urbanas en Ciudad de Buenos Aires.

No sólo se trata de hacer historia; el supuesto fundamental del artículo es que el análisis propuesto constituye un paso más hacia la comprensión de la disputa actual por el acceso y permanencia de los pobres en la ciudad. ¿De qué modo las políticas públicas moldearon el componente reivindicativo de la organización territorial? ¿Las demandas y luchas de los villeros, ganaron terreno en el diseño de las políticas urbanas? ¿De qué modo?

Según Oszlak y O’Donnell (1981) las políticas públicas son procesos complejos, tejidos por interacciones objetivas y subjetivas entre la sociedad y el estado a lo largo del tiempo. Este trabajo indaga en dichas interacciones, en los momentos en que los diferentes actores definieron la cuestión, sus necesidades y demandas socialmente problematizadas en diferentes momentos de su historia. ${ }^{2}$

Detrás de cada definición de política pública hay disputas, representaciones, fundamentos y modelos de sociedad. Son formas de representar el mundo en el que colaboran en la determinación de conductas socialmente aceptadas y rechazadas. Las diferentes concepciones del mundo que circulan en la sociedad en un momento determinado sostienen principios ideológicos y éticos que entran en pugna y forman el sentido común (Gramsci 2013).

Un supuesto fundamental de este trabajo es que el componente urbano del bienestar asume en las clases populares un lugar protagónico. El bienestar "resume un conjunto de prestaciones que el Estado financia (parcial o totalmente), regula y articula con otras esferas (mercado y familia) para posibilitar el acceso a bienes que la sociedad acuerda como necesarios y por lo tanto no pueden depender solo de la capacidad de competencia de las personas en el mercado de trabajo (Clemente 2020:12). Su estudio supone tanto al Estado y su rol de proveedor y distribuidor, como un análisis de un conjunto de actores individuales y colectivos que a través de sus prácticas, reivindicaciones y demandas disputan las concepciones institucionalistas. Según Merklen "la exclusión respecto a la vivienda significa más que el impedimento de contar con cuatro paredes y un techo. Es exclusión del acceso a la tierra en tanto componente del hábitat y a la propiedad como sustento jurídico y simbólico, como muro de contención frente a la inseguridad social. Es exclusión de la posibilidad de 'acceder, progresar, llegar...', con la cual en algunos casos antes se contaba” (1997a: 52).

Componente urbano, entonces, hace referencia a lo que Oszlak llamó "derecho al espacio urbano": "El derecho al uso y disposición del espacio urbano (...) la capacidad de fijar el lugar de residencia o de localización de la actividad económica dentro del espacio, capacidad que puede extenderse a la disposición unilateral de los bienes que ocupan o a la participación en procesos de decisión sobre obras de infraestructura y servicios 
colectivos en espacios públicos y privados adyacentes" (Oszlak [1991] 2017: 33). Pero también refiere al acceso a una vivienda adecuada. Es decir, que sus ocupantes gocen de la seguridad de su tenencia, agua potable, instalaciones sanitarias y eléctricas adecuadas, que el diseño se adecúe a las necesidades de los usuarios y respete la identidad cultural, que su costo no ponga en peligro el disfrute de otros satisfactores básicos.

La hipótesis general de este trabajo es que a partir de la última dictadura cívico militar (1976-83) se fue dando, con los cambios en la acumulación capitalista y las cuestiones socialmente problematizadas, una re-individualización y descolectivización ${ }^{3}$ (Castel 2010) en las prácticas de las organizaciones villeras. Específicamente, se sostiene que las organizaciones poco a poco abandonaron la impronta de la organización obrera para asumir nuevas características vinculadas a las nuevas políticas urbanas focalizadas orientadas al sector.

Con el fin de abordar estos aspectos el artículo se estructura en seis partes. El primer apartado aborda la especificidad del movimiento villero en tanto movimiento urbano territorial. En el segundo se exponen las características asumidas por la organización durante la década de 1970, un periodo de radicalización política de las clases populares. A continuación se incluye un apartado acerca de los profundos cambios que se llevaron adelante durante la última dictadura cívico militar y sus consecuencias en la estructura urbana y (des)organización territorial. En cuarto lugar, se trabaja el período de apertura democrática y las características del nuevo perfil que asumió la organización política en general, y el movimiento villero en particular. Finalmente, se aborda el periodo de reformas neoliberales de los 90 y se concluye con unas reflexiones que procuran abrir horizontes para pensar los problemas de acceso a la ciudad de los sectores más vulnerables. ${ }^{4}$

\section{1. ¿La política en el territorio o el territorio de la política?}

Hacia fines del siglo pasado, la desindustrialización y el desmantelamiento del sistema productivo dieron lugar al surgimiento del territorio como nuevo principio de socialización. Hasta entonces, la fábrica y el sindicato habían funcionado como principio ordenador de las relaciones sociales y políticas. Se produjo lo que muchos especialistas definieron como la territorialización de las formas organizativas de las clases populares (Merklen 2005; Svampa 2005).

Robert Castel argumentó que el trabajo asalariado es el epicentro de la cuestión social. ${ }^{5}$ Según el autor, un trabajo estable garantiza la integración de las personas a la sociedad en la que viven, el acceso a las condiciones requeridas para tener un lugar y ser reconocido como individuo en todos sus derechos. Por el contrario, la ausencia de trabajo pone en cuestionamiento esa integración. Si bien el sociólogo francés reconoce la importancia de otros componentes de la vida social -como el urbano- su hipótesis es que aún con el fin de la sociedad salarial el epicentro sigue siendo el trabajo y los cambios en ese ámbito repercuten 
en las diferentes esferas de la existencia social (Castel 2010). Las transformaciones que vienen dándose desde hace más de cuarenta años en los modos de organización y la centralidad adquirida por el territorio en la subjetivación política hallarían su explicación en los cambios acontecidos en el mundo laboral.

Los estudios de Jacques Donzelot (2012) se ubican en contraposición a este planteo.A partir de una serie de conflictos urbanos acontecidos en los suburbios de varias ciudades europeas, el autor concluyó que la conflictividad social, otrora cristalizada en el ámbito laboral, ahora se presenta en el espacio. Propone para ello pensar la ciudad como una nueva dimensión de la ciudadanía. En la escala local, dice el autor, se asiste a una desconexión entre las oportunidades de empleo y las poblaciones pobres, y este problema -señala- no gira en torno a la relación de fuerza social sino que proviene de los desequilibrios espaciales. Existe una desigualdad espacial antes que social. Una nueva ciudadanía urbana, consistiría en un acuerdo entre los representantes locales electos, los habitantes, las prestatarias de servicios y los empresarios que le den respuestas a esa problemática.Teóricos como Manuel Castells (1974) y Jordi Borja (1975) analizaron en la década de 1970 el fenómeno de las organizaciones aglutinadas a partir de demandas por el acceso a la ciudad bajo el concepto "movimientos sociales urbanos". Los definieron como "sistemas de prácticas sociales contradictorias que controvierten el orden establecido a partir de las contradicciones específicas de la problemática urbana" (Castells 1974, 3).

Las villas llevan en sí algo profundamente político. Su conformación, desarrollo y mantenimiento requieren de la organización de los vecinos para la reproducción de la vida y la provisión del bienestar. Esa organización es entendida como una forma organizativa de la clase obrera a partir de una identidad territorial (Snitcofsky 2015). Este hecho se relaciona con lo que Denis Merklen (2005) llamó “politicidad”. En su estudio acerca de las clases populares luego de finalizada la última dictadura cívico militar en el país, el autor utilizó esta noción para nombrar la condición política de una persona: "El concepto engloba al conjunto de sus prácticas, su socialización y su cultura política” (Merklen 2005: 24). La politicidad se presenta como un aspecto constitutivo de la identidad de los individuos, en el que sociabilidad y política se ven entremezcladas.

La organización territorial en las villas porteñas tiene una larga historia. Hasta 1958 las villas de la ciudad de Buenos Aires contaron con organizaciones relacionadas principalmente con el deporte y el esparcimiento. También con instituciones como las Juntas Vecinales y los Clubes de Madres, pero su funcionamiento era esporádico dado que la mayoría de los vecinos era gente de trabajo y los encuentros y actividades resultaban de dificil coordinación (Ratier, 1971).

El país estaba inmerso en un desarrollo industrial por sustitución de importaciones que absorbía una gran cantidad de mano de obra y generaba una movilidad social 
ascendente en la población. Se trataba de una estructura social dinámica. Este hecho explica la inexistencia de organizaciones más robustas que estructuraran su demanda alrededor de las condiciones de vida. Las villas se presentaban como un lugar de paso hacia la vivienda definitiva. Esa situación que no generaba en sus habitantes la necesidad de organizarse en torno a reivindicaciones del hábitat.

Cuando el modelo de industrialización por sustitución de importaciones empezó a mostrar sus primeras limitaciones y, en 1955, con el golpe de Estado al gobierno peronista, la situación cambió. Las economías rurales y regionales perdieron vitalidad y la inmigración desde el interior del país no cesó. Ambos factores generaron una tasa de crecimiento de la población urbana mayor al crecimiento de la población industrial. Se creó una masa de marginados del proceso productivo con inserción inestable en el mismo (Nun 2001); una expansión del área metropolitana; y se consolidaron las formas precarias del hábitat (Cravino 2006).

Alicia Ziccardi (1977), estudió la relación entre movimientos sociales urbanos y políticas de vivienda. En una de las investigaciones pioneras acerca del Movimiento Villero, la autora vinculó los motivos que llevaron a los pobladores de las villas de la ciudad de Buenos Aires a organizarse con la crisis de la vivienda:

El surgimiento $y$ desarrollo de distintas formas organizativas de los residentes de las villas de emergencia se recuesta indudablemente sobre el problema de la crisis de la vivienda. Una de las expresiones de esa crisis original de los países dependientes, es la formación de asentamientos urbanos deteriorados. Esa forma de residencia paupérrima constituye una alternativa habitacional a la que deben recurrir vastos sectores populares (...) Sin embargo, la existencia de las villas no determina necesariamente la aparición de estructuras organizativas ligadas a las mismas. Su posibilidad emerge del hecho de que los residentes de las villas a partir de sus necesidades colectivas inmediatas se agrupen en su demanda alrededor de algún tipo de organización que las vehiculice

(Ziccardi 1977: 16).

Asimismo, señaló diferencias entre organizaciones internas y externas. Con las primeras refirió a un conjunto de organizaciones cuya existencia era producto de la acción colectiva emprendida por los habitantes de las villas, organizaciones recreativas, reivindicativas y sectoriales; las segundas eran aquellas promovidas por instituciones del estado o de la sociedad civil. En un trabajo más reciente, Cravino (s.f) realizó una nueva diferenciación 
entre organizaciones de primer orden, vinculadas centralmente con la reproducción de la vida, el deporte y el esparcimiento; y de segundo orden, más complejas, relacionadas con las reivindicaciones del hábitat.

A lo largo de la historia el movimiento villero sufrió cambios cualitativos y cuantitativos asociados tanto a las políticas urbanas orientadas al propio sector como a las transformaciones económicas que se dieron durante la última mitad del siglo XX. Poco a poco la villa dejó de ser visualizada como una situación más de carencia de vivienda y pasó a constituirse como una cuestión socialmente problematizada. La estadía transitoria comenzó a ser permanente. Se generaron estructuras organizativas más compleja que tenían la finalidad de representar al conjunto y demandas más nutridas (Ziccardi 1977).

Hacia 1970 el movimiento villero estaba conformado por trabajadores que capitalizaron en el territorio prácticas organizativas vinculadas al sindicalismo de base (cuerpos de delegados, comisiones vecinales, coordinadoras). Contaban con una organización superior en la que confluían los representantes de todas las villas de la ciudad y, en ocasiones, articularon sus reivindicaciones y acciones de lucha con las organizaciones obreras (Snitcofsky 2014). Sin embargo, luego de la última dictadura cívico militar ese esquema se modificó. Si bien en esa época los estudios sobre las formas organizativas se direccionaron hacia los procesos de tomas de tierras en el conurbano bonaerense, es posible retomar algunas características para pensar el fenómeno de villas en la ciudad. Merklen (1997b) observó en la construcción de un barrio a partir de la toma ilegal de tierras un nuevo sentido de integración que había sido puesto en cuestión en otros ámbitos de la vida social como el laboral. La hipótesis del autor fue que la relación de las clases populares con la política debía ser explicada a partir de las transformaciones sociales y no desde la situación económica.

¿Qué pasa en las villas? Camelli (2017) utilizó la categoría "politicidad” de un modo diferente. Si bien Merklen analizó con esa noción los modos de subjetivación política y las prácticas desplegadas por las clases populares en un contexto de declive del capitalismo industrial en el país, Camelli desplazó la categoría en el tiempo y con ella analizó el proceso de organización villera desde su conformación a mitad de siglo XX. A través de ella aprehendió el dinamismo de la construcción colectiva en los barrios populares de la ciudad de Buenos Aires. La autora sugiere que "las organizaciones barriales fueron las primeras experiencias de prácticas colectivas en las villas, y en ellas podemos identificar la génesis de una práctica política constituida en torno al territorio. De este modo, logramos identificar a la política como una actividad fundante y constitutiva en sociabilidad villera" (Camelli 2017: 87).

La idea que guió a esta autora es que en estos espacios urbanos se dio desde el comienzo una práctica política específica. En principio porque los vecinos se tuvieron que 
organizar para resolver cuestiones inmediatas y vitales, pero en segundo término porque se organizaron en torno a prácticas reivindicativas sobre el hábitat. Este hecho es señalado como una característica inédita, y lo denomina "politicidad villera".

En este punto, se instala la pregunta acerca de si la organización villera se presentó como una expresión o anticipación de un fenómeno que terminó de irrumpir en las últimas décadas del siglo pasado, o se está en frente a algo nuevo. Si la inclusión siempre incompleta del componente urbano en el del bienestar en la agenda social hizo que desde sus orígenes el movimiento villero otorgue sentido de integración a amplias capas de población pobre de la ciudad; o si el fenómeno de territorialización de las organizaciones populares a fines del siglo pasado presentó nuevas características.

¿Cuáles fueron esas características? ¿Cómo fue el proceso de transformación? ¿Qué lugar tienen las políticas urbanas en la explicación de dicho proceso? son algunas de las preguntas de surgen a partir de lo revisado. El supuesto de este artículo es que lejos de ser el territorio un nuevo emergente, hacia finales del S XX la organización se debilitó. Nuestra hipótesis es que esa territorialidad se vincula con una individualización y descolectivización de la organización popular que marcará el desempeño de las organizaciones villeras y la evolución de la agenda de políticas urbanas en la Ciudad de Buenos Aires.

Al tomar en cuenta esta serie de antecedentes, resta para el artículo abordar de un modo exploratorio las características que asumió la organización, en tensión y diálogo con las políticas urbanas implementadas. Se hará énfasis en los cambios que se produjeron con el retorno de la democracia.

\section{Radicalización política del movimiento villero}

En 1958, de la mano de la Federación de Villas y Barrios de Emergencia, surgió en las villas de la ciudad una estructura organizativa compleja que buscó representar al conjunto del sector. La organización, relacionada con el Partido Comunista, capitalizó la representación de los pobladores villeros. Sus reivindicaciones estuvieron centradas en la participación estatal, por lo que el accionar de las diferentes juntas y comisiones vecinales estuvo fuertemente condicionado por la actitud que tomaron los organismos públicos en cada gobierno según fuera constitucional o dictatorial.

Hacia finales de la década de 1960, las persistentes agresiones por parte del Estado, el no reconocimiento legal de las organizaciones y el empobrecimiento cada vez mayor de los sectores populares, llevaron a que el movimiento villero ya no levantara consignas asistencialistas y reclamara respuestas a la inserción productiva. Más trabajo, mejor salario y la conformación de barrios obreros. A principios de los años setenta se conformó el Frente Villero de Liberación Nacional que al poco tiempo se convirtió en el 
Frente Villero Peronista de Liberación Nacional y luego se fusionó con el Movimiento Villero Peronista. Éste último fue uno de los frentes de masas de la estrategia política de Montoneros (Gillespie 1987). El proceso significó una profunda radicalización en la que sus dirigentes lograron ejercer presión suficiente como para reorientar las intervenciones oficiales dirigidas al sector (Snitcofsky 2015).

Entre las principales demandas y reivindicaciones del periodo se enumeran la expropiación de las tierras dónde se ubicaban las villas; el derecho a mantener esa ubicación; en caso de ser relocalizadas que ello fuera dentro de la ciudad y cerca de lugar en el que existían hasta entonces; participación de los vecinos en el diseño de las nuevas viviendas; que el monto de la cuota de la hipoteca fuera fijo, sin ajustes, y no superara el 10\% de los ingresos del hogar; que las viviendas en las que los villeros residían hasta el momento fueran tomadas como parte de pago; la suspensión de pago de la cuota en caso de que el trabajador quedara sin trabajo; y, por último, un trabajo estable con salario justo para los residentes de las villas (Dávolos et al, 1987; Snitcofsky, 2015).

En simultáneo con este proceso, los trabajadores de la Comisión Municipal de laVivienda (CMV) conformaron un Cuerpo de Delegados y una Comisión Interna, hegemonizados ambos por la Juventud de Trabajadores Peronistas (JTP). Davolos et al (1987) se preguntan respecto de la relación entre el movimiento villero y el Estado si es posible comprender a este último sólo como un instrumento de las clases dominantes o si su carácter está, más bien, determinado por las personas que lo manejan. Para responder el interrogante las autoras tomaron un periodo concreto de la historia del país, la transición democrática de 1973, y un organismo del Estado, la Comisión Municipal de la Vivienda (CMV). Observaron el surgimiento de un poder alternativo, o incipientes formas de poder popular, a partir de la alianza estratégica entre el personal de la CMV y el movimiento villero.

La alianza se vio plasmada en el Plan Piloto Villa $7 .{ }^{6}$ En 1971 surgió desde la CMV la oportunidad de construir un nuevo barrio de viviendas. Se trató de un plan de carácter experimental. El lugar seleccionado para llevarlo adelante fue la Villa 7 del barrio de Mataderos, debido a su pequeña escala. ${ }^{7}$ Desde su concepción se procuró marcar algunas diferencias con la política habitacional que se venía desarrollando hasta ese momento. El punto de partida de la intervención era de respeto por lo existente, tanto de las organizaciones barriales como la identidad de los residentes con el lugar. En segundo término, el eje estuvo en la participación de la comunidad en todas las etapas del proceso: tanto en la determinación de las necesidades como en la elaboración y control. Además, se trataba de una relocalización conjunta de toda la comunidad en el sitio en el que se hallare localizada: una primera experiencia de radicación.

Según Barrios (2015), el de Villa 7 fue un programa que no sólo presentó una gestión participativa, también fue la primera experiencia que se propuso mejorar el problema 
de la vivienda a partir del mejoramiento del hábitat y no desde una mirada restrictiva que proponía atacar la problemática a partir de las condiciones de la vivienda entendida de modo restrictivo, como unidad física.

Desde el organismo ejecutor se implementó el traslado de la sede del equipo de trabajo al territorio. Esta mudanza les permitió no sólo entablar otro tipo de lazos con la población, sino también abordar mejor una serie de objetivos-hipótesis que se habían propuesto: desarrollar una concepción de trabajo en equipo entre pobladores y trabajadores de la CMV; crear un nuevo modo de trabajo con la comunidad; y reducir los costos de construcción al incorporar empresas pequeñas y pobladores en la etapa de producción.

El último objetivo coincidía, a su vez, con una de las máximas reivindicaciones del Movimiento Villero: la creación de cooperativas o empresas populares. Las mismas eran concebidas por la organización como un germen de autogobierno "donde los pobladores hacen escuela en la administración y adquieren experiencia de poder" (Diario La Opinión, apud Snitcofsky 2015: 184). Por esta vía se buscaba construir una institución sólida que pudiera dar trabajo a las clases populares, pero también entenderse con las áreas ejecutivas del Estado y ejercer presión para una mayor participación política.

Dos integrantes de la Junta Vecinal de Villa 7 plantearon en un artículo publicado en El Descamisado:

Aparte de la importancia de que Villa 7 se va a mudar a hogares dignos -explican los compañeros Rímoli y De Cario, titulares de la Junta Vecinal-, lo importante de esta obra es la participación popular en todos los niveles. Acá hay compañeros que empezaron de ayudantes y hoy son oficiales albañiles. Los villeros aprendimos un oficio, nos hicimos nuestras casas y ahora vamos a trabajar construyendo casas para otros compañeros de otras villas. Una vez por semana nos reunimos con la Comisión Municipal de la Vivienda y discutimos y planificamos. Los que trabajan acá reciben buenos sueldos, con todos los beneficios sociales. ${ }^{8}$

El testimonio citado hace referencia a otro de los puntos centrales que abarcaba el proyecto: la vivienda digna. A partir de las necesidades determinadas por los pobladores, desde el diseño y la arquitectura se procuró construir un barrio que contemplara diversidad de edificios, espacios de recreación y encuentro, la construcción de una guardería infantil y de locales amplios, iluminados y asoleados, destinados a una proveeduría y usos múltiples. Para las viviendas se consideró un estándar que oscilaba entre 12.5 y $10 \mathrm{~m}^{2}$ por habitante, 
los dormitorios fueron ubicados en zonas silenciosas y se consideró la posibilidad de cambios internos y crecimientos futuros. El programa estuvo constituido por 122 unidades que incluyeron 7 tipologías, desde el monoambiente hasta 7 dormitorios.

La etapa de transición democrática (1972-1973) tuvo en el movimiento villero un gran desarrollo organizativo dado no sólo por la propia acumulación política sino también por una nueva alianza estratégica con las áreas ejecutoras del Estado. Este hecho les permitió crecer, dar un salto cualitativo en las demandas y reivindicaciones. Incorporaron como puntos centrales la radicación in situ, la participación de los pobladores en todas las etapas de la política habitacional, y la creación de empresas populares para la producción de sus propios barrios. Cuestiones que se materializaron en una experiencia piloto. La radicación no sólo era posible, sino el que el barrio obrero ahora tenía nombre y cara.

El triunfo electoral de la alianza FREJULI ${ }^{9}$ en 1973 y el retorno de Perón al país abrieron para el campo popular en general, pero para el movimiento villero en particular, la esperanza de una nueva etapa de oportunidades. Los villeros habían participado activamente de la campaña electoral y como fuerza integrante del nuevo gobierno ubicaban su intervención en el proceso de reconstrucción nacional a partir de la conformación de empresas populares. Estas tenían el propósito de abaratar costos de producción, crear fuentes de trabajo para el pueblo humilde, instituirse como un actor capaz de debatir las políticas de bienestar social y contribuir a la nacionalización del Estado, al romper con el monopolio de empresas extranjeras. En este nuevo contexto la organización adquirió una escala nacional que se vio reflejada en dos congresos multitudinarios.

El primer Congreso NacionalVillero fue realizado en la ciudad de Santa Fe en octubre del 73. Contó con la presencia de 2.500 delegados representantes de siete provincias: Buenos Aires, Chaco, Córdoba, Entre Ríos, Jujuy, Salta, Santa Fe y la Ciudad de Buenos Aires. Ésta última sola reunía 1.200 participantes. En el encuentro el Movimiento Villero Peronista se definió como una organización político-reivindicativa que tenía por objetivo apoyar, defender y controlar al nuevo gobierno popular. En palabras del documento final, se trataba de sostener medidas que promovieran el empleo y la eliminación de la explotación, que abogaran por la expropiación de las tierras donde estaban ubicadas las villas y propulsaran la construcción de nuevas viviendas. También se establecía resguardar al gobierno de ataques externos, pero a su vez examinar su accionar. ${ }^{10}$ La experiencia del golpe de Estado a Salvador Allende en Chile un mes antes marcaba un antecedente a tener en cuenta.

El tercer gobierno peronista, a través de su ministro de economía José Ber Gelbard, planteó un "Pacto Social". Después de largos periodos de crisis económicas y de una perdida sustantiva del ingreso por parte de los trabajadores, el nuevo acuerdo suponía una alianza entre capital y trabajo mediada por el Estado. En términos de política pública supuso el armado del "Plan Trienal para la Reconstrucción y la Liberación Nacional". ${ }^{11}$ Si bien se 
trataba de un plan que procuraba austeridad en el gasto público, la construcción masiva de vivienda por parte del Estado era un punto estratégico. La justificación estaba dada por el rol fundamental de la actividad constructiva en la reactivación económica, ésta estimulaba la inversión privada a la vez que generaba un número importante de nuevos empleos. Recién en segundo lugar la política se planteaba como objetivo permitir el acceso a la vivienda a sectores sociales con limitada o inexistente capacidad de ahorro y reducir el déficit habitacional de las clases populares (Ziccardi 1984).

El Ministerio de Bienestar Social (MBS), dirigido por José López Rega, era el encargado de poner en práctica el programa de vivienda que tuvo tres líneas de acción:

- Plan Alborada: destinado a los residentes de las villas de emergencia, rancheríos, pensiones o viviendas precarias, gente en situación de calle y residentes de áreas fronterizas. Se trataba de conjuntos habitacionales definitivos, en unidades individuales o colectivas con equipamiento comunitario;

- Plan Eva Perón: préstamos individuales para aquellas familias que contaran con un terreno de no menos de $200 \mathrm{~m}^{2}$ en propiedad para construir la vivienda propia; - Plan 17 de octubre: préstamos hipotecarios para la construcción de viviendas de sindicatos, cooperativas, asociaciones $\sin$ fines de lucro, ahorristas del Banco Nacional, mutualistas y entidades comerciales.

La línea destinada a los sectores más vulnerables, lejos de asemejarse a la experiencia piloto deVilla 7 vinculada con las principales reivindicaciones del movimiento villero, implicaba cierta continuidad con las políticas de los gobiernos dictatoriales. La construcción masiva de viviendas nuevas dejaba implícito un proceso de erradicación de villas que se contradecía con las demandas de expropiación de tierras y el mejoramiento de las viviendas existentes o construcción de nuevas viviendas en sus localizaciones originales.

Mientras las organizaciones villeras apostaban por la creación de empresas populares, el gobierno inclinaba su balanza a la inversión privada y sellaba una alianza con la "patria contratista": un grupo de grandes empresas cuyas ganancias provenían históricamente de contratos con el Estado. Estas discrepancias reflejaban la tensión subyacente al interior de la alianza de gobierno. El MBS representaba la derecha peronista y el Movimiento Villero tenía una clara identificación con el ala izquierda, particularmente con la organización Montoneros. Desde el organismo ejecutor no se abrieron instancias de diálogo y la implementación de la política tuvo más bien un carácter autoritario. 
Si por una parte los villeros no lograron instituirse como interlocutores e instalar sus planteos respecto a la problemática de villas, por otra la cuestión se convirtió, de acuerdo a Ziccardi (1984), en una lucha ideológica. Lo que estaba en juego y en discusión no era la pregunta acerca de por qué existían las villas de emergencia y cómo se reproducían, sino cuál era la mejor estrategia para solucionar el problema. Las dos opciones en disputa se encuadraban, a su vez, en lógicas de poder globales. De un lado se propulsaba el desarrollo del poder popular y la autonomía de los villeros, mientras que del otro se apuntaba al control y accionar estatal (Yujnovsky 1984).

Esta disputa fue el halo del segundo Congreso Nacional Villero en enero de 1974. En esta oportunidad asistieron 500 delegados de diferentes villas del país. Las confrontaciones con el gobierno marcaron un retroceso respecto de la agenda del primer Congreso. Si bien se mantuvieron las reivindicaciones sobre la conformación de empresas populares, el eje estuvo en la participación. Entre las conclusiones principales destacaron el pedido de reconocimiento oficial del Movimiento Villero Peronista, un lugar para éste en la alianza de gobierno y la conformación de espacios de trabajo a los que pudiera llevar sus planteos:

"pedir la oficialización de las mesas de trabajo ya existentes y la creación de otras en todas las áreas de gobierno, a nivel nacional, provincial o municipal, $y$ concretamente recomendar la creación de esas mesas en el Ministerio de Bienestar Social, con el fin de que los villeros podamos ejercer en esa forma un control de los proyectos y ejecuciones de ese Ministerio". ${ }^{12}$

El declive del movimiento se volvió definitivo cuando al retornar de Córdoba, en una reunión entre representantes del MVP de la Ciudad de Buenos Aires y el presidente Perón, el líder inclinó la balanza a favor de los intereses del MBS:

Es nuestro deseo erradicar totalmente las villas de emergencia, especialmente por los chicos, porque son peligrosas. Es allí donde surgen las epidemias por falta de servicios $y$ de higiene natural porque están apiñados uno encima del otro y porque están en zonas de contaminación, que es otra cosa que hay que ir eliminando. ${ }^{13}$

Los dichos de Perón, sumados a los primeros hechos de violencia política cometidos por la organización "Triple A" hacia los villeros, abrieron una nueva etapa. ${ }^{14}$ Ese año, en el marco del plan Alborada, se relocalizaron los sectores Saldías, Laprida y Comunicaciones de la Villa 31, en Ciudadela, Municipio de Tres de Febrero; al año siguiente vecinos de la villa Bajo Belgrano fueron relocalizados en el conjunto habitacionalVilla Soldati. Los acontecimientos marcaron el comienzo de un retroceso en la organización política. 
El periodo que concluía fue el de un movimiento villero con demandas y reivindicaciones que no sólo trascendían su territorio sino que suponían un tipo bienestar que desafiaba las políticas urbanas vigentes. La nueva etapa habría de caracterizarse por un repliegue de la organización, acciones de resistencia y cese de la movilización.

\section{3. "Alguien lo tiene que hacer"}

La frase que titula este acápite fue dicha por el gerente de la CMV, el Comisario policial Salvador Lotito, encargado de llevar adelante el plan de erradicación de villas de mayor virulencia histórica (Oszlak [1991] 2017). Esta política se implementó a la par de fuertes transformaciones estructurales.

El cambio del modelo de acumulación capitalista a mediados de la década de los años setenta implicó un trastrocamiento en las concepciones sobre bienestar hasta esos momentos vigentes. En palabras de Castel (2015) se pasó de una sociedad salarial a un cada vez más preocupante aumento de las incertidumbres. En términos concretos esto significó una mayor debilidad del Estado de Bienestar, la erosión de las estructuras de defensa de los intereses de los trabajadores, por lo tanto, desempleo masivo y precarización laboral y, finalmente, un aumento del individualismo.

Durante la última dictadura cívico militar se sentaron las bases para un el ordenamiento urbano desigual orientado a facilitar el desarrollo de todo tipo de negocios privados (Rodríguez y DiVirgilio, 2013). Se crearon nuevas institucionalidades dirigidas a la expansión de un tipo de negocio que tiene a la ciudad como objeto y soporte (Rodríguez et a.l 2015) y se intensificaron los contrastes y yuxtaposiciones entre las clases sociales (Pírez 2016, Ciccolella 1999).

En julio 1977, a un año de la toma del poder por las Fuerzas Armadas, la Municipalidad de Buenos Aires publicó la ordenanza no 33.652, de "Erradicación de villas de emergencia". Si bien ésta guardaba algunas líneas de continuidad con los planes implementados en el periodo previo, el alcance de las erradicaciones, la cantidad de habitantes afectados, la falta de alternativas de acceso a la vivienda, la extensión de la superficie desocupada y el nivel de violencia ejercido en los desalojos, hicieron de esta política algo inédito (Snitcofsky, 2015).

La erradicación de villas debe ser entendida en el marco de un plan general para toda la Región Metropolitana de Buenos Aires; se trataba de tener bajo control su crecimiento. De este modo se dio fin a los loteos populares en la provincia, se descongelaron los alquileres y se construyendo autopistas (Herzer et al. 1995). De acuerdo a Oszlak, las políticas urbanas aplicadas en el periodo tuvieron un carácter revolucionario que rompió con el estilo incremental que se había mantenido hasta el momento. Una de las características fundamentales con respecto a la erradicación de villas fue que los interlocutores de la política estatal esta vez no eran sus destinatarios inmediatos sino la población en general. Para llevar adelante su 
plan, los militares se posaron sobre prejuicios preexistentes en la sociedad y se propusieron como solución radical al problema (Oszlak [1991] 2017).

En 1976 residían en la ciudad de Buenos Aires 224.885 habitantes de villas, un 8\% del total de la población de la ciudad ((Blaustein, 2006, Oszlak cit.). El número incluye a los residentes de Núcleos Habitaciones Transitorios (NHT) y los vecinos de los barrios Rivadavia, García y Mitre, que lejos de ser villas de emergencia eran barrios obreros cuyos habitantes estaban pagando al Banco Hipotecario la cuota de su vivienda. Al finalizar la dictadura en 1983, según los datos de la Municipalidad de Buenos Aires, vivían en las villas de la ciudad 12.593 personas (Snitcofsky 2014a).

El hostigamiento al movimiento villero comenzó dos años antes de producirse el golpe militar. Según los testimonios recolectados en diferentes investigaciones (Bellardi y De Paula, 1986; Snitcofsky, 2015; Blaunstein, 2006) en la villa 21-24, por ejemplo, antes de la publicación de la ordenanza 33.652 toda la cúpula de la Junta Vecinal había sido asesinada por elementos militares. En la Villa 31 la violencia política comenzó, ya se dijo, en 1974. De acuerdo a Bellardi y De Paula (1986) las políticas llevadas adelante durante este periodo pudieron implementarse porque el Movimiento Villero ya estaba desarticulado.

En este punto resulta pertinente citar los estudios de Ana Jemio (2019) respecto al Operativo Independencia. La autora retomó a Marín (2007) y postuló que la destrucción de los cuerpos del campo popular durante el periodo previo al golpe militar puede considerarse un proceso de ruptura, de disociación y quiebre de los vínculos y alianzas tejidas en la lucha entre diferentes sectores del campo popular. No se trataba de perseguir a los cuadros armados sino de romper las articulaciones logradas, que eran la gran fuente de poder. Esas rupturas profundas habilitaron el avance de la violencia genocida, que tuvo como blanco "las relaciones de clase que a lo largo de los últimos cien años, trabajosa, contradictoria y largamente, habían logrado instalarse entre la mayoría de los obreros en la Argentina" (Marín 2007: 36).

Pese a la represión ilegal, los villeros retomaron sus memorias de organización y lograron articular reivindicaciones en torno de una serie de iniciativas. En esta oportunidad, el aliado estratégico fue el Equipo Pastoral Villero. Las primeras acciones realizadas por el grupo fueron: el envío de cartas a las autoridades competentes; la publicación de opiniones y solicitadas en los medios de comunicación para contrarrestar la imagen negativa difundida en la opinión pública; el trabajo con la población afectada acerca de cómo proceder en los desalojos; y, por último, reclamos frente a las autoridades eclesiásticas.

También en el marco de esta alianza, hacia fines de 1978, diferentes villas de la ciudad comenzaron a organizar con el apoyo de Cáritas cooperativas de autoconstrucción asistida, para resolver de manera definitiva el problema de la vivienda. Esta experiencia, que contaba 
con el antecedente del Plan Piloto Villa 7, tuvo la potencia de representar una alternativa distinta; fue el paso de la ilegalidad a la propiedad de la tierra y el cambio de una estrategia individual de solución al problema de la vivienda a una comunitaria. Su limitación consistió en no poder preservar el lugar de residencia, el derecho a la centralidad y a preservar la vida cotidiana construida durante años. Los nuevos barrios autoconstruidos se ubicaron fuera de la ciudad, en el Gran Buenos Aires (Cuenya, Pastrana yYujnovsky, 1984).

Otro de los destinos que tomó la población erradicada fue la toma de tierras en el sur del conurbano. En 1981, 4.600 familias (alrededor de 20.000 personas), tomaron 211 ha. ubicadas entre San Francisco Solano (municipalidad de Quilmes) y Rafael Calzada (Almirante Brown). Este hecho representó una novedad en las formas de producir el hábitat. Hasta ese momento la práctica más habitual entre los sectores populares era lo comúnmente llamado asentamiento de hormiga, tomas de tierras progresivas enmarcadas en iniciativas individuales o familiares. En este caso se trató de una iniciativa colectiva y organizada.

Izaguirre y Aristizabal (1988) consideraron este acontecimiento como un modo de reestructuración de los frentes de lucha populares. Al igual que en otras reivindicaciones del periodo, la Iglesia Católica y las comunidades eclesiales de base fueron el factor aglutinante. Un gran porcentaje de familias había sido víctima del proceso de erradicación; también había ex inquilinos a los que la desregulación de precios de los alquileres había obligado a migrar al Gran Buenos Aires (GBA), inmigrantes de otras provincias despojados de oportunidades ante la quiebra de las economías regionales y recientes desocupados. La experiencia acumulada se vio reflejada en una forma de organización similar a la obrera fabril y, por ende, a su adaptación a la base territorial en las villas de la ciudad. Los recientes barrios se organizaron por delegados de manzana, comisiones internas y comisión coordinadora.

Mientras tanto en las villas de la ciudad quedaban familias resistiendo los desalojos. Hacia fines de 1979 el régimen dictatorial sufrió sus primeras fracturas políticas y militares. En este contexto las protestas y demandas públicas de los afectados se multiplicaron. A partir de una alianza de las familias con la Asociación de Abogados de Buenos Aires surgió la Comisión de Demandantes. El objetivo fue adoptar una estrategia judicial. La misma se valía del inciso C del artículo 2 de la ordenanza de 1977: “crear condiciones para que los grupos familiares asentados en las villas puedan acceder a viviendas decorosas", y pedirle al gobierno de facto el cumplimiento de la norma. Luego de un primer revés judicial, un nuevo fallo hizo lugar a un amparo de las familias afectadas y declaró precautoriamente la medida de "no innovar", no demoler viviendas mientras no terminara el juicio (Konfino, 2015). La medida cautelar fue citada luego para la defensa de las familias residentes en las restantes villas de la ciudad.

Si bien durante este periodo surgieron nuevos liderazgos, la política de erradicación masiva arrasó la territorialidad social (Jemio, 2019; Silveyra, 2018). Esta suponía la construcción 
de poder popular, la puesta en juego de las formas de vinculación y reconocimiento con los otros que se daba en territorios concretos, en este caso las villas. Estas eran lugares donde la fuerza social del campo popular tomaba forma; en ellas confluían diferentes agrupamientos y se daban relaciones sociales de solidaridad, reciprocidad y horizontalidad. eran espacios donde los sectores populares le daban sentido a la unidad, articulaban interpretaciones de la realidad, de los problemas que los rodeaban y sus posibles soluciones.

Juan Gutiérrez, ex miembro del Equipo Pastoral Villero, lo expresó así:

Cuando vino la dictadura, la topadora no solamente te rompió las casas. Sino que tocó todo, rompió los cables, las cloacas. La topadora levantó todo, movimientos sociales, personas, el tejido social. Todo destruyó. Las villas no fueron lo mismo después de la dictadura que antes de la dictadura. La conformación, la gente. Gente nueva, gente mezclada, aparecieron las rejas". ${ }^{15}$

No obstante haber resistido y organizado iniciativas territoriales, en este periodo comenzó un proceso de abandono de aquellos horizontes que traspasaban la vida barrial. Si antes de 1974 los villeros se propusieron como un actor capaz generalizar sus demandas, debatir la política sectorial y los destinos del desarrollo nacional, después del genocidio ese universo se achicó:

La gente se volvió a nuclear en la Pastoral Villera. Teníamos una secretaria de tierra y vivienda, de juventud, de deportes, de comunicación, de salud, de todos los quilombos que había. Porque éramos bomberos. Íbamos a apagar los fuegos: instalaciones eléctricas para la miércoles, etcétera, etcétera. Había que estar en la urgencia de cada día más que en la transformación social (ibid).

La nueva organización, surgida de las entrañas del proceso de desarticulación, fue en gran parte conducida por la Iglesia Católica -al menos en un primer momento- que sólo se ocupó de responder necesidades situadas de los sectores más vulnerables. Las disputas quedaron puertas adentro de los barrios. Como menciona Gutiérrez, había que resolver la urgencia más que la transformación social. Al igual que en todo el campo popular, iniciaba en las villas un proceso de re-individualización y descolectivización.

\section{Repoblamiento de villas, apertura democrática y pobreza urbana}

En el nuevo escenario post-dictatorial el diagnóstico generalizado fue que el cambio en los patrones de acumulación capitalista y la crisis económica que se vivía en aquel entonces 
traería aparejado un crecimiento de los asentamientos precarios y del sector informal de la economía. La pobreza alcanzó a sectores urbanos que hasta entonces se sentían inmunes a ella, y las administraciones locales se vieron cada vez más desbordadas económica, social, cultural, política y administrativamente para gestionar la ciudad. Se entendía, además, que la pobreza urbana no sólo había llegado para quedarse sino que se incrementaría en las próximas décadas.

En la década de 1980 se abrió una etapa de diálogo en el campo de la vivienda popular, donde continuaron, con un renovado apoyo, los procesos de autoconstrucción asistida que habían comenzado durante el régimen militar. Por ejemplo La cooperativa Copacabana de la Villa 31 construyó 108 viviendas; Madre del Pueblo, de la Villa 1-11-14, otras 178; Caacupé, de la Villa 21-24, 61 viviendas; 5 de Noviembre, de laVilla 20, 211; y otras tantas construyeron las cooperativas conformadas enVilla INTA, Cildáñez, Pirelli y algunos asentamientos del GBA.

En paralelo se repoblaron las villas de la ciudad. Muchas familias que habían sido desalojadas, pero también ingentes cantidades de nuevos pobres, ocuparon los terrenos y construyeron sus casas. En noviembre de 1984 el entonces intendente Julio César Saguier, a través de la ordenanza 39.753, anuló las normas de erradicación creadas por el gobierno militar y aprobó pautas programáticas para la radicación y la solución integral de las villas y NHT. La nueva norma no sólo otorgó derechos a quienes vivían en ese momento en las villas sino también a aquellos que pudieran acreditar haber sido desalojados en el periodo anterior. De acuerdo a Juan Gutiérrez (entrevista citada)

Toda esa lucha primero fue la emergencia y después la protección. Se logró una ley, la famosa ley 39.753. Fue antes de cristo y después de cristo. Digo yo, o sea, la 39.753, acuérdense, es la que sacaba la palabra erradicación y por primera vez se hablaba de radiación.

Este hecho representó un cambio de paradigma respecto a toda la política urbana orientada a villas y asentamientos que se había implementado hasta entonces. Por un lado, suponía un triunfo de las históricas reivindicaciones del movimiento villero; por otro, respondía al nuevo enfoque internacional promovido desde 1976 por UN- Hábitat basado en la radicación, la participación popular y la autoconstrucción asistida (Cuenya y Yujnovsky 1878; Cuenya, Gazzoli y Yujnovsky (1979).

Sin embargo los barrios asumieron otras características: "La villa no es como era antes", "antes podíamos estar juntos"; “antes las casitas eran de puertas abiertas, ahora hay rejas y todos desconfian de todos”, son algunos de los testimonios que Juan Gutiérrez (1999: 82) recuperó de esa época; la nueva pobreza, o los nuevos villeros -agregaba- llevaban en el cuerpo la memoria de la erradicación. Feierstein (2007) sostuvo que el genocidio perpetrado por la dictadura actuó sobre la sociedad existente, la reorganizó; clausuró 
todas las relaciones que causaban fricciones o mediaciones en el ejercicio del poder y las reemplazó por una relación unidireccional con el mismo.

La "reorganización nacional" buscaba precisamente lo que hoy nos encontramos: que la sociedad estuviera atomizada en infinidad de reclamos individuales, en miles de caracterizaciones imposibles de dialogar entre sí, en multiplicidad de identidades encerradas en sí mismas, encapsuladas en su mero interés corporativo, incapaces ya no de indignarse sino siquiera de darse por enterados de las necesidades del otro (2007: 360).

A su vez, otros fenómenos que son necesarios tener en cuenta para comprender las dificultades que asumirá la nueva organización territorial, que marcan -en cierto modo- sus límites y contornos, son el del narcotráfico y la delincuencia. Estas nuevas ilegalidades también actúan horadando las relaciones sociales existentes a partir del ejercicio de una violencia criminal (Feierstein, 2018). Esta va desde una criminalidad popular, espontánea, movida por la necesidad y vinculada al hurto o robo oportunista, hasta una criminalidad organizada en redes, articulada con fuerzas de seguridad corrompidas y, muchas veces, con estructuras regionales o transnacionales.

Pese a las nuevas circunstancias, en 1987 se conformó el Movimiento deVillas y Barrios Carenciados (MVBC). En su declaración de principios se puede leer la intención de representar al conjunto de villas, NHT, asentamientos y barrios marginados de toda la ciudad, el denominador común fue "la falta de vivienda digna y, además, el estar viviendo en condiciones de marginados sociales" (Gutiérrez 1999). La finalidad que el MVBC se propuso era "terminar para siempre con nuestra condición de ciudadanos de segunda". En tercer lugar, su reivindicación fundamental se centró en la radicación definitiva: "reconocer el derecho a la titularidad de la tierra que habitamos, de todos los que vivimos en las Villas y Barrios carenciados de la Capital Federal”.

El MVBC se reconoció como la continuidad histórica y legítima de las luchas villeras. En línea con la Comisión de Demandantes, era un espacio pluralista que no se identificaba con la política partidaria, ponía el relieve su esencia democrática y el protagonismo de las organizaciones naturales de base. La estructura organizativa del movimiento contaba con tres instancias: la mesa colegiada, que se reunía semanalmente y tenía poder de decisión y ejecución, participaban de ella dos representantes de cada barrio o villa, y dos representantes de la Pastoral Villera; los plenarios, que se realizaban mensualmente con el fin de escuchar necesidades de los vecinos; y la asamblea, que constituía la instancia de mayor decisión y ejecución (Gutiérrez, 1999; Camelli, 2011). 
En 1989, con la designación de Carlos Grosso como intendente de la ciudad de Buenos Aires, el MVBC logró darle cause a sus propuestas a partir de la conformación de la Mesa de Concertación. La finalidad de este espacio era delinear el proyecto de radicación definitiva. Estaba integrado por la mesa colegiada del MVBC; las secretarías de planeamiento urbano, obras públicas, calidad de vida; la escribanía mayor de gobierno; y la procuración general.

El entonces Secretario de Planeamiento Urbano, Alfredo Garay, explicó el funcionamiento del espacio, la llamativa ausencia de la CMV y el trabajo que allí se realizaba:

Entonces bueno, una vez a la semana en mi oficina venían todas las villas. La reivindicación fue la regularización de la tenencia de la tierra (...) Las reuniones fueron teniendo una rutina y el objetivo era regularizar. Nos llevó un motón de trabajo que hicimos todos los que estábamos ahí. Había una decisión que era complicada: el título o la vivienda. Venía muy marcado por la impronta del proceso, todavía los empleados del instituto de la vivienda seguían siendo los mismos que los del proceso militar. Entonces, lo que hice fue sacar el tema de villas de la CMV y ponerlo en la secretaría de planeamiento. ${ }^{16}$

El ex cura Juan Gutiérrez rememoró una conversación que mantuvo en 1996 con el ex presidente Raúl Alfonsín (1983-89) acerca de la política de villas de su gobierno. El ex mandatario le consultó a Gutiérrez su opinión acerca de la gestión desarrollada en las villas durante su periodo de gobierno. Frente a la respuesta desalentadora del interrogado, Alfonsín "reconoció la ausencia de una acción efectiva, pero al mismo tiempo remarcó que justamente en eso consistió la apertura democrática: el permitir que los diversos sectores sociales hayan podido manifestarse y ejercer sus derechos a la libre expresión" (Gutiérrez 1999: 87).

En términos reales, el periodo estuvo más cercano a un dejar hacer que al hacer mismo. Fue una etapa donde primó la recuperación de ámbitos democráticos de diálogo, pero sin acciones efectivas ni políticas direccionadas a resolver las problemáticas de las villas en la ciudad. Antes de la dictadura cívico militar, las organizaciones vinculaban sus condiciones urbanas al mundo del trabajo y a las necesidades de los trabajadores. La reivindicación de un ‘barrio obrero' significaba demandarle al Estado las mismas condiciones de vida que sus pares de las fábricas, pero además suponía entender la problemática habitacional en términos de conflictos de clase.

La primavera democrática inauguró un periodo donde los pobres, cada vez más, fueron entendidos como un sector -y no una clase-al que la sociedad debía ayudar. Comenzaba un 
distanciamiento. Si antes el movimiento villero era concebido como una forma organizativa de la clase obrera, entendido como sector, la tarea del Estado consistía, entonces, en sacarlos de las condiciones en las que se encontraban, y ya no en modificar las condiciones.

\section{Territorialización: individuación y descolectivización}

La última década del siglo pasado encontró a la organización villera focalizada en una demanda: la tierra. Con las erradicaciones en la memoria reciente y las experiencias de autoconstrucción asistida del conurbano de la provincia de Buenos Aires, la nueva agenda de bienestar se centró en la seguridad de la tenencia: "Primero era la lucha por la tierra. Tiene que estar la tierra y tenemos que tener bancos de tierra. Era la temática nuestra. Sobre ellos iban calles y sobre ellos iban los servicios, y luego sobre ellos iban la vivienda. Pero primero la tierra. La urbanización estaba lejos, pero queríamos la lucha por la tierra. Una ley nacional de tierra.” (entrevista a J. E. Gutiérrez, cit.).

En 1990 el presidente Carlos Menem firmó, ante la presencia de las organizaciones villeras, el decreto 1001/90, por el que se declararon innecesarios los terrenos ociosos pertenecientes a la Empresa Ferrocarriles Argentinos, Administración General de Puertos, Mercado Nacional de Hacienda, Subsecretaría de Hacienda de la Nación , del Ministerio de Salud y Acción Social y del Banco Hipotecario Nacional, y se habilitaba la venta a sus ocupantes. Meses después, la Municipalidad de la Ciudad de Buenos Aires emitió el decreto 1737/90 que resolvió de modo similar la situación de los terrenos municipales. Por un lado, la sanción de la norma significaba el reconocimiento de un derecho y del reclamo histórico de los vecinos; por otro, el marco general de privatización del Estado le daba a este decreto un carácter mercantil que se alejó de cualquier concepto de política social.

El Programa Arraigo, la traducción política de estas medidas, supuso un desplazamiento de la vivienda de la agenda del bienestar y representó una desconcentración de las responsabilidades del Estado en manos de las organizaciones villeras. Para vender las tierras se eligió como contraparte una figura asociativa (cooperativas, mutuales, fundaciones). Una vez conformada dicha figura, los vecinos debían comprar terrenos que no sólo no cumplían con la normativa urbana (infraestructura básica, mesura, cota hidráulica), sino que además debían abonar un interés real de deuda del $8 \%$.

A su vez, el Estado creaba rispideces hacia el interior de los territorios. Las asociaciones que representaban a los vecinos solían ser elegidas arbitrariamente por las autoridades, pero además debían constituirse como cobradoras. En caso de que alguno de los integrantes no pagara la deuda, la misma debía ser asumida por el resto de los asociados. Este cuadro de responsabilidades se completaba a la hora de firmar el boleto de compra-venta. En esa instancia se consideraba un congelamiento en el crecimiento de las villas, no debían ingresar más vecinos. El cumplimiento de ese requisito también recaía sobre los hombros de las organizaciones. 
En este punto se tensionaba el empoderamiento popular y la autogestión. Si por un lado las organizaciones villeras contaban con experiencias de autogestión asistida y veían en esta medida un modo de potenciar su organización; por el otro, el Estado se desligaba de todo tipo de responsabilidades y el derecho reconocido se convertiría en una trampa para los más pobres.

La lógica de la política pública implementada fue resquebrajando la legitimidad del movimiento villero. Muchos referentes fueron corrompidos o deslegitimados por el gobierno local. En el marco de la radicación las agencias estatales eligieron a sus interlocutores. Si por un lado este hecho les daba legitimidad a los dirigentes, la participación también supuso un alto costo político hacia el interior de los barrios:

Esta elección en sí misma es un acto de legitimación o por lo menos de diferenciación en las organizaciones $u$ los dirigentes barriales cuando éstas o éstos son varios, como suele existir en la mayoría de los casos. Los organismos de la radicación necesitaron un interlocutor barrial. No se partió de un conocimiento de la realidad (a partir de un relevamiento o investigación) o de la concertación, sino que se quiso construir un intermediario a la medida, como sucedió con el movimiento villero. Este mecanismo se convirtió en un bumerang porque terminó destruyendo a sus propios interlocutores

(Cravin, s/f, 14).

A su vez, los villeros se vieron atravesados por la interna del Partido Justicialista. Pero el conflicto central fue la incorporación, mediante la firma de un convenio con el Gobierno de la Ciudad de Buenos Aires, de muchos de sus miembros a las estructuras estatales, algo que fue leído como una clara acción de clientelismo político (Camelli 2011). Tanto en las entrevistas realizadas como en análisis académicos existe una coincidencia en marcar este periodo como el del gran golpe a las organizaciones villeras. En la visión de Juan Gutiérez (entrevista citada)

El problema de los compañeros es muy difícil ¿no? El dirigente más indigente de los barrios antes no estaba tan contaminado. Era la lucha, la solidaridad, etcétera. Pero claro, esa persona tiene que comer, tiene que vivir. (...) Era un quilombo estar todo el día en la lucha. Era lógico. A ver, la solidaridad pura si, el pobre folclórico no existe. Lo que pasa es que el que realmente te va a ayudar cuando se te esté quemando el rancho ¿quién te va a pagar? El vecino. Pero después en el día a día, viste. Porque esto to hicimos entre todos, esto lo levantamos entre todos, la 
capilla pero también había hambre ¿viste? tenía que garparle (pagarle: JN), ¿viste? (...) Entonces yo creo que el dirigente o el referente de los barrios tenía que tener un sueldo, yo mismo reconocí viste. Ese tipo que después de estar todo el día luchando por el barrio, yendo de un lado al otro, de una casa a otra, la cloaca, el incendio, hospital. $Y$ si tengo viáticos para eso (...). De ahí se pasa al otro extremo, ¿viste? al final ser mercenario.

Al promediar la década, durante la gestión de Julián Domínguez (1994-1996), se terminó con los espacios participativos iniciados años antes. La Mesa de Concertación fue desarmada y se retomó el uso de la violencia para amedrentar a los vecinos de la villa 31 y obligarlos al desalojo.

Sin embargo la sanción de la nueva Constitución Nacional (1994) trajo consigo la autonomía de la ciudad, que sancionó su propia Constitución en 1996. En el capítulo quinto "Hábitat", su artículo 31 reconoció el derecho a la vivienda digna y su hábitat adecuado. La incorporación de este artículo, aunque sólo fuera en términos normativos, representó un gran avance en la lucha de los pobres por el acceso y permanencia en la ciudad. ${ }^{17}$

Hacia 1998 el MVBC ya había perdido credibilidad entre los habitantes villeros y su representatividad era cuestionada. Esto derivó en que un grupo de dirigentes se unieran y conformaron la Federación de Villas, NTH y barrios marginales de la Ciudad de Buenos Aires (FEDEVI). El propósito fue construir una organización verdaderamente representativa, donde la prioridad estaba en respetar las discusiones y decisiones tomadas por las bases (Camelli 2011).

Ese mismo año se logró la sanción de la Ley 148 "De atención prioritaria a la problemática social y habitacional en las Villas y Núcleos habitacionales transitorios”. La norma ordenaba la creación de una Comisión Coordinadora Participativa para el diagnóstico, propuesta, planificación y seguimiento de la ejecución de las políticas sociales habitacionales. Ésta sería integrada por un representante del poder ejecutivo de la ciudad, uno del poder legislativo, y por parte de los vecinos, un representante por cada villa o NHT que haya sido elegido en comicios regulares, tres de la FEDEVI y tres del MVBC.

Entre las funciones de dicha comisión estaba el diseño de los lineamientos generales de un programa integral de radicación y transformación de villas y NHT, realizable en 5 años. Éste programa debía contemplar: un relevamiento integral de los barrios; la regularización dominial; la urbanización integral (apertura de calles, desarrollo de infraestructura de servicios, regularización parcelaria y creación de planes de vivienda social); el fortalecimiento de la infraestructura de servicios y la recuperación de las áreas urbanas 
adyacentes; el desarrollo de políticas sociales activas e integrales y el equipamiento social, sanitario, educacional y deportivo; la planificación presupuestaria participativa de los recursos; y la incorporación, a través de metodologías autogestionarias, de los pobladores afectados al proceso de diagramación, administración y ejecución del programa.

Pese a los avances normativos, el fin de siglo encontró al país inmerso en una crisis económica y social sin precedentes dónde el cumplimiento de dichos mandatos resultó imposible. A su vez, se configuró un nuevo perfil del movimiento villero que con los años se iría profundizando. Con los lazos sociales desgastados, los pobladores organizados remitieron sus demandas exclusivamente a las necesidades territoriales. Entre tanto el Estado se mantuvo en los mínimos sociales al separar la vivienda de la agenda de bienestar social. Este periodo habría de marcar un nuevo ciclo en el cual el diálogo con las políticas urbanas se dará de forma fragmentada, con ausencia de un sujeto colectivo y dificultades para tensionar la agenda de gobierno.

\section{Reflexiones finales}

Al comienzo de este artículo se plantearon cuestiones e interrogantes acerca del diálogo que se estableció entre el movimiento villero, sus modos organizativos, demandas y reivindicaciones, y las políticas urbanas. De qué modo habían interactuado y qué factores influyeron en sus reconfiguraciones.

En función a esas preguntas iniciales se detectaron periodos de rupturas y negociación donde a veces se vieron tensionadas las reivindicaciones y otras el componente urbano de la agenda de bienestar. Un primer ciclo que inicia a fines de la década de 1960, una ruptura que comenzó en 1974 y finaliza con la última dictadura cívico militar, la apertura democrática y el restablecimiento del diálogo, y finalmente, la etapa de reformas neoliberales que tuvo el movimiento villero como blanco.

De modo preliminar se vio el paso de una articulación de demandas que desafiaban la política pública y proponían nuevas alternativas como solución, no sólo a los problemas de las villas sino también al desarrollo nacional, a la configuración de un nuevo perfil organizacional cerrado en su propio territorio con demandas de carácter situado, dirigentes incorporados en el sistema político y desconcentración del Estado en la organización popular.

Entre fines de los años sesenta y principios de los setenta el movimiento villero asumió las características de un frente de masas a escala nacional. Sus reivindicaciones incluían la radicación definitiva en las tierras ocupadas, el desarrollo de empresas populares, la construcción de viviendas dignas y la conformación de barrios obreros. Mientras desde la política pública predominó como solución la erradicación y la construcción de grandes complejos de viviendas, los villeros sostuvieron la consolidación de sus barrios, dentro de un proyecto de desarrollo nacional. La complejidad del Estado y la fortaleza del campo popular en el 
periodo hicieron que, pese a las resistencias, se pueda llevar adelante un plan piloto (Villa 7) que hasta el día de hoy aparece como ejemplo de una política exitosa y participativa.

Se señaló cómo el último régimen cívico militar, cuyas políticas urbanas reordenaron el territorio de la ciudad, se propuso eliminar todo tipo de resistencia y atacó la potencia del lazo social que durante años se había consolidado en los territorios. El movimiento villero es un espejo de la derrota del campo popular en general, de la acumulación de rupturas de relaciones sociales que luego serán capitalizadas por las clases dominantes.

Sin embargo, fue un proceso complejo y contradictorio. Fue posible observar, por ejemplo, cómo las intervenciones propuestas a partir del retorno de la democracia tendieron a alinearse con las históricas reivindicaciones del movimiento villero. Pero al encontrarse diezmado, empobrecido y reconfigurado, la conducción política en el nuevo escenario resultó más costosa. Poco a poco fue atravesado por las nuevas lógicas de poder. Esto supuso un proceso de creciente descolectivización de la protesta, el quiebre de alianzas estratégicas y la atomización de las demandas. Durante el proceso de reformas neoliberales la agenda de bienestar se centró en la tierra, mientras que la vivienda y la urbanización se vieron desplazadas.

En este punto es importante señalar que no se trata de realizar idealizaciones, ni el movimiento de los años 70 era un sujeto colectivo consiente y homogéneo, ni el del fin de siglo es pura fragmentación e individualismo. Hay una latencia de las formas organizativas, de su conciencia del hacer y su matriz de organización original. Una memoria y una práctica colectiva que alguna veces prevalece y otras se desdibuja. A fin de siglo XX, ese acumulado se puso en juego en procesos como la sanción de la ley 148 o la incorporación de un artículo sobre el hábitat en la Constitución de la ciudad.

Respecto al carácter territorial, prevalece el interrogante acerca de si la inclusión siempre tensionada del componente urbano en el del bienestar en la agenda social hizo que desde sus orígenes el movimiento villero otorgue sentido de integración a amplias capas de población pobre de la ciudad, o si el fin de siglo trajo tras de sí un nuevo fenómeno de politicidad territorial. A partir de lo analizado, es posible arriesgar que no se trata de una politicidad villera o una forma diferente de hacer política, sino que hacia finales del siglo pasado el movimiento villero tuvo una suerte de adecuación y adaptación de sus demandas y expectativas a las ofertas políticas del Estado.

Hacia la década del 90, se vio un alejamiento de las estructuras obreras tradicionales, acorde con el proceso de desafiliación, individualismo y descolectivización de la sociedad argentina general. La organización villera asumió una nueva impronta más ligada a su territorio. Esta transformación puede ser leída como el preámbulo de un proceso de descomposición o como desafio para comprender las dificultades organizativas en los procesos de urbanización actuales en la ciudad. 
Sobre el potencial transformador de estos cambios, el teórico británico David Harvey (2014) sugirió que, así como en el siglo XIX Marx instaló la pregunta acerca de las potencialidades revolucionarias del proceso de producción en las fábricas, en el siglo XXI urge reflexionar acerca de las potencialidades transformadoras de la vida en la ciudad y los movimientos urbanos. ¿Qué pasa -sugiere el autor- si ampliamos la concepción de trabajo colectivo fabril a la metrópoli como un vasto bien común producido por el trabajo colectivo que nos está siendo enajenado?

¿Qué pasa si se retoma la politicidad villera como un potencial transformador para pensar no sólo los barrios populares sino la propia ciudad? La posibilidad de una nueva conducción política del proceso y la configuración, a futuro, de un proyecto de carácter autónomo que garantice entre los componentes del bienestar el acceso y permanencia en los sectores vulnerables en la ciudad se presentará como el desafio del nuevo milenio. 
${ }^{1}$ Este artículo se enmarca en una investigación general acerca de las políticas de re-urbanización de villas de la Ciudad Autónoma de Buenos Aires (CABA) en el periodo 2016-2019, con foco en el Proyecto Integral de Re-urbanización (PIRU) Villa 20. Dicho estudio busca comprender las disputas de sentidos en torno a la urbanización y la re-significación, desde el punto de vista de los actores, del bienestar, su producción y la vinculación con el hábitat y su transformación.

2 "Ninguna sociedad posee la capacidad ni los recursos para atender omnímodamente a la lista de necesidades y demandas de sus integrantes. Sólo algunas son 'problematizadas', en el sentido de que ciertas clases, fracciones de clases, organizaciones, grupo o incluso individuos estratégicamente situados creen que puede y debe hacerse 'algo' a su respecto y están en condiciones de promover su incorporación a la agenda de problemas socialmente vigentes. Llamamos 'cuestiones' a esos asuntos (necesidades, demandas) 'socialmente problematizados”' (Oszlak y O’Donnell 1981).

${ }^{3}$ Estas últimas son características que provienen de la sociología laboral y se utilizan para caracterizar el régimen post-industrial. Consisten en una exhortación a ser individuo y en un abandono creciente del sujeto colectivo como sujeto social capaz de organizar las demandas y garantizar derechos. En términos del movimiento villero, se pasó de cuestionamiento y desafío a las políticas urbanas, de un proyecto de desarrollo nacional, a reivindicaciones situadas en lo local con serias imposibilidades para generalizar las demandas.

${ }^{4}$ Para llevar adelante este trabajo se relevaron artículos académicos y publicaciones periodísticas como Cristianismo y revolución, El descamisado, Evita Montonera. También se tuvieron en cuenta producciones literarias y una serie de biografias publicadas en el último tiempo acerca de referentes emblemáticos del movimiento villero. Por último, se realizaron entrevistas con actores clave de las organizaciones territoriales y de las áreas ejecutivas del Estado (realizadas en el marco del proyecto de reconstrucción de la memoria del Movimiento Villero a partir de la historia oral, dirigido por la Dra. Mónica Lacarrieu).

5 “La 'cuestión social' es una aporía fundamental en la cual una sociedad experimenta el enigma de su cohesión y trata de conjurar el riesgo de su fractura. Es un desafio que interroga, pone de nuevo en cuestión la capacidad de una sociedad (lo que en términos políticos se denomina una nación) para existir como un conjunto vinculado por relaciones de interdependencia" (Castel 1999:16) [...] "La 'cuestión social' puede caracterizarse por la inquietud acerca de la capacidad para mantener la cohesión de una sociedad. Amenazan con la ruptura ciertos grupos cuya existencia hace vacilar la cohesión del conjunto. ¿Cuáles son? El problema se complica en este punto, debido al desdibujamiento del término 'social' (...) Las poblaciones que son objeto de intervenciones sociales difieren fundamentalmente según sean o no capaces de trabajar, y en función de este criterio se las trata de maneras totalmente distintas" (Castel 1999:29) ${ }^{6}$ Los datos utilizados para describir el Plan fueron extraídos de una nota de Miguel Cangiano, trabajador de la CMV, incluida en el anexo documental de Davolos et al (1987).

${ }^{7}$ Actual complejo Justo Juárez ubicado en la intersección de la calle Belgrano y Avenida Lisandro de la Torre. 8 "Para construir las casas de los villeros nadie mejor que el pueblo villero" en El Descamisado, Año I-N³2-24 de diciembre 1973.

${ }^{9}$ El Frente Justicialista de Liberación fue una alianza electoral formada en 1972, integrada por el Partido Justicialista (PJ) con otros partidos como el Movimiento de Integración y Desarrollo (MID), el Partido Conservador Popular y el Partido Popular Cristiano (PPC). Las elecciones se realizaron el 11 de marzo de 1973. La fórmula del FREJULI obtuvo el 49,56\% de los votos y superó a la de la Unión Cívica Radical que obtuvo un 21,29\%.

10 “Congreso Nacional Villero.Villeros Peronistas, unidos y organizados hacia la libración” en El Descamisado, Año I, N 24, 30 de octubre de 1973, pp. 10-13.

${ }^{11}$ Vid. República Argentina, (1973) Plan Trienal para la reconstrucción y la liberación nacional 1974-1977’. Poder Ejecutivo Nacional, diciembre.

12 "El Parlamento villero". Revista YA! . Enero 1974, p. 28.

13 "Hacia un país sin villas miserias". El Caudillo. Año II, número 12, febrero 1974.

${ }^{14}$ La "Alianza Antocomunista Argentina, conocida como "Triple" fue una organización terrorista, parapolicial, dependiente del ministro López Rega. Después del golpe de Estado del 29/3/76 pasó a actuar como parte del esquema represivo de la dictadura. En marzo de 1974, durante una manifestación frente al Ministerio de Bienestar Social, fue asesinado Alberto Chejolán, vecino el Barrio Güemes en la Villa 31 de Retiro, miembro del Centro Vecinal y del Movimiento Villero Peronista; un hecho adjudicado por la opinión pública a la Triple A. En mayo de ese mismo año la Triple A asesinó en la villa 31 al padre Carlos Mugica.

${ }^{15}$ Entrevista de la autora a Juan Gutiérrez, septiembre 2019.

${ }^{16}$ Entrevista de la autora al Arq. Alfredo Garay, 29 de mayo de 2019.

${ }^{17}$ Art. 31: "La Ciudad reconoce el derecho a una vivienda digna y a un hábitat adecuado. Para ello: 1. Resuelve progresivamente el déficit habitacional, de infraestructura y servicios, dando prioridad a las personas de los sectores de pobreza crítica y con necesidades especiales de escasos recursos. 2. Auspicia la incorporación de los inmuebles ociosos, promueve los planes autogestionados, la integración urbanística y social de los pobladores marginados, la recuperación de las viviendas precarias y la regularización dominial y catastral, con criterios de radicación definitiva. 3. Regula los establecimientos que brindan alojamiento temporario, cuidando excluir los que encubran locaciones." 


\section{Referencias bibliográficas}

Barrios, R. (2015) "Políticas de gestión del hábitat y organización popular en la ciudad de Buenos Aires. El Plan Piloto de Realojamiento de laVilla 7 y Construcción del barrio Justo Suárez (1971- 1975)". Ponencia presentada en el Seminario de Crítica. Instituto de Arte Americano e Investigaciones Estéticas "Mario J. Buschiazzo". Facultad de Arquitectura, Diseño y Urbanismo, Universidad de Buenos Aires. www.iaa.fadu.uba.ar/publicaciones/critica/0199.pdf

Bellardi, Marta y Aldo De Paula (1986) Villas Miseria: origen, erradicación y respuestas populares. Buenos Aires: Centro Editor de América Latina.

Blaustein, E. (2006) Prohibido vivir aquí. La erradicación de las villas durante la dictadura. Buenos Aires, Editorial Punto de Encuentro.

Borja, Jordi (1975) Movimientos sociales urbanos. Buenos Aires, Ediciones SIAP.

Camelli, Eva (2017) “La ocupación silenciosa del espacio. Conformación y crecimiento de villas en la Ciudad de Buenos Aires, 1930-1958”. Cuaderno urbano. Espacio, cultura y sociedad 22:73-90.

Camelli, Eva (2011) "Las organizaciones políticas en las villas de Buenos Aires: entre la radicalidad sesentista y la fragmentación neoliberal”. Revista Estudios sobre Genocidio, 5:5871.

Castel, Robert (2015) La inseguridad social ¿Qué es estar protegido?.Buenos Aires: Manantial.

Castel, Robert (2010) El ascenso de las incertidumbres. Trabajo, protecciones y estatuto del individuo. Buenos Aires, Fondo de Cultura Económica.

Castel, Robert (1999) La metamorfosis de la cuestión social. Una crónica del salariado. Buenos Aires, Paidós.

Castells, Manuel (1974) Movimientos sociales urbanos. Buenos Aires, Siglo XXI editores.

Ciccolella, P. (1999) “Globalización y Dualización en la Región Metropolitana de Buenos Aires: Grandes inversiones y reestructuración socioterritorial en los años noventa". Eure 25 (76) 5-27 (Santiago de Chile).

Clemente,Adriana (coord.) (2020) El bienestar en retroceso. El caso de las políticas asistenciales ante la incertidumbre: 2016-2019. Buenos Aires: Departamento de Publicaciones de la Facultad de Ciencias Sociales de la Universidad de Buenos Aires. 
Cravino, María Cristina (2006) Las villas de la ciudad. Mercado e informalidad urbana. Buenos Aires, Universidad Nacional de General Sarmiento.

Cravino, M. C. (s.f) "Las organizaciones villeras en la Capital Federal entre 1989-1996. Entre la autonomía y el clientelismo". Disponible en: < https://acij.org.ar/wp-content/ uploads/Las_organizaciones_villeras_en_la_Capital_Federal_entre_1989.pdf>

Cuenya, Beatriz y Oscar Yujnovsky, Oscar (1978) «Vancouver recommendations for national action: Preliminary report on Latin America case-studies», en Habbitat International, vol. 3 n³-4, pp. 299-308.

Cuenya, Beatriz, Ernesto Pastrana y Oscar Yujnovsky (1984) De la villa miseria al barrio autoconstruido. Buenos Aires, Ediciones CEUR.

Cuenya, Beatriz, R. Gazzoli y Oscar Yujnovsky (1979) Políticas de asentamientos humanos., Buenos Aires, Ediciones CLACSO/SIAP.

Cuenya, Beatriz, R. Gazzoli y Oscar Yujnovsky (1979) Políticas de asentamientos humanos., Buenos Aires, Ediciones CLACSO/SIAP.

Dávolos, P, M. Jabbaz y E. Molina. (1987) Movimiento villero y Estado (1966-1976). Buenos Aires: Centro Editor de América Latina.

Donzelot, Jacques (2012). ¿Hacia una ciudadanía urbana? La ciudad y la igualdad de oportunidades. Buenos Aires, Nueva Visión.

Esping-Andersen, Gøsta (1993) Los tres mundos del Estado de Bienestar.Valencia,Alfons el Magnanim.

Gramsci, Antonio (2013) Antología. Buenos Aires: Siglo XXI Editores.

Feierstein, D. (2018) Los dos demonios (recargados). Buenos Aires, Marea Editorial.

Feiersten, D. (2007) El genocidio como práctica social. Entre el nazismo y la experiencia argentina. Buenos Aires, Fondo de Cultura Económica.

Gillespie, R. (1987) Soldados de Perón. Los Montoneros. Buenos Aires, Grijalbo.

Gutiérrez,J. E. (1999) La fuerza histórica de los villeros. Buenos Aires, Juan Baudino Ediciones. 
Herzer H. M.; M. Carman; M.M. Di Virgilio; S. Lago Martínez; M. Lanzetta; A. Redondo y M.C. Rodríguez (1995) Hábitat popular, organizaciones territoriales y gobierno local en el área metropolitana de Buenos Aires : análisis comparativo de dos estudios de caso. Buenos Aires:Instituto de Investigaciones Gino Germani, Facultad de Ciencias Sociales, Universidad de Buenos Aires.

Izaguirre, Inés y Zulema Aristizábal (1988) Las tomas de tierras en la zona sur del Gran Buenos Aires: un ejercicio de formación de poder en el campo popular. Buenos Aires, Centro Editor de América Latina.

Jemio, A. S. (2019) El Operativo Independencia en el sur tucumano (1975-1976). Las formas de la violencia estatal en los inicios del genocidio. Tesis para optar por el título de doctora en Ciencias Sociales, Facultad de Ciencias Sociales, Universidad de Buenos Aires.

Konfino, D. (2015) Patria Villera. Villa 31 y Teófilo Tapia: historia de una lucha. Buenos Aires, Ediciones Ciccus.

Marín, Juan Carlos (2007) Los hechos armados, Argentina 1973-1976: la acumulación primitiva del genocidio. Buenos Aires, La Rosa Blindada.

Merklen, Denis (2005) Pobres ciudadanos. Las clases populares en la era democrática (Argentina, 1983-2003). Buenos Aires, Editorial Gorla.

Merklen, Denis (1997a) “Un pobre es un pobre”. Revista Sociedad 11:21-64.

Merklen, Denis (1997b). “Organización comunitaria y práctica política. Las ocupaciones de tierras en el conurbano de Buenos Aires”. Nueva Sociedad 149:162-177.

Nun, José (2001) Marginalidad y exclusión social. Buenos Aires, Fondo de Cultura Económica.

Oszlak, Oscar ([1991] 2017) Merecer la ciudad. Los pobres y el derecho al espacio urbano. Buenos Aires, Eduntref.

Oszlak, Oscar y Guillermo O’Donnell (1981) "Estado y políticas estatales en América Latina: hacia una estrategia de investigación”. Buenos Aires: Documento del Centro de Estudios de Estado y Sociedad (CEDES).

Pírez, Pedro (2016) "Buenos Aires: la orientación neoliberal de la urbanización metropolitana”. Sociologías, 18 (42) 90-118.año 18 Nº 42.

Ratier, H. E. (1971) Villeros y Villas Miseria. Buenos Aires, Centro Editor de América Latina. 
Rodríguez, M. C.; M.M. DiVirgilio; S.Arqueros Mejica; M. F. Rodríguez y M. C. Zapata (2015) "Contradiciendo la Constitución de la Ciudad. Un análisis de los programas habitacionales de la Ciudad de Buenos Aires en el período 2003-2013" en Documentos de trabajo N79, Instituto de Investigaciones Gino Germani, Facultad de Ciencias Sociales, UBA, CABA, Argentina.

Rodríguez, M. C. y M. Di Virgilio (2013) "Ciudad de Buenos Aires: políticas urbanas neoliberales, transformaciones socio-territoriales y hábitat popular”. Ponencia en el Seminario Internacional A Cidade Neoliberal na América Latina: desafios teóricos e políticos, Río de Janeiro, Brasil.

Sen Amartya K. (1997) Bienestar, justicia y mercado. Barcelona: Ediciones Paidós.

Silveyra, M. (2018) "Aproximaciones al concepto de genocidio desde una perspectiva marxista. Aportes para comprender el caso argentino". Conflicto Social. Revista del Programa de Investigaciones sobre Conflicto Social. 11 (20) 143-170.

Snitcofsky, Valeria (2015) "Villas de Buenos Aires. Historia, experiencia y prácticas reivindicativas de sus habitantes (1958-1983)". FiloDigital Repositorio Institucional de la Facultad de Filosofia y Letras de la Universidad de Buenos Aires.

Snitcofsky, Valeria (2014) "Organización territorial y continuidad histórica: aportes a la luz de los congresos nacionales del Movimiento Villero Peronista (1973 y 1974)". Trabajo y sociedad. Sociología del trabajo 22:377-393.

Svampa, Maristela (2005) La sociedad excluyente. La Argentina bajo el signo del neoliberalismo. Buenos Aires: Taurus.

Yujnovsky, Oscar (1984) Claves Políticas del problema habitacional argentino 1955-1981. Buenos Aires: Grupo Editor Latinoamericano.

Ziccardi, Alicia (1977). "Políticas de vivienda y movimientos urbanos. El caso de Buenos Aires (1963-1973)". Buenos Aires: Centro de Estudios urbanos y regionales. Documento de trabajo. Buenos Aires.

Ziccardi, Alicia (1984) “El tercer gobierno peronista y las villas miseria de la ciudad de Buenos Aires (1973-1976”. Revista mexicana de sociología volumen XLVI, N 4:145-172.

\section{Cómo citar este artículo:}

Nesprias, Julia (2021) "Transformaciones del movimiento villero y las disputas por el the bienestar en las políticas urbanas de la Ciudad de Buenos Aires (1970-2000)". Revista Perspectivas de Políticas Públicas vol. 10 № 20:397-427 